\title{
Ontogeny of Hepatic Peroxisomal Uricase Activity in the Mongrel Puppy
}

\author{
PETER F. WHITINGTON AND F. BRUDER STAPLETON WITH THE TECHNICAL ASSISTANCE OF \\ DANA A. NASH AND SHARON R. GROSS
}

Department of Pediatrics, Sections of Gastroenterology and Nephrology, University of Tennessee Center for the Health Sciences and LeBonheur Children's Medical Center, Memphis, Tennessee, USA

\section{Summary}

Activities of uricase, catalase, and acid phosphatase were measured in the light mitochondrial subcellular fraction of liver from late fetal, neonatal, and adult dogs in order to examine the hypothesis that diminished hepatic peroxisomal uricase activity is responsible for elevated plasma uric acid concentrations in newborn puppies. Late fetal dogs had slightly lower uricase activity than 1-day-old puppies (1.4 \pm 1.0 (S.D.) and $3.9 \pm 0.7 \times 10^{-5}$ $\mu$ mole hydrolyzed $/ \mathrm{min} / \mathrm{g}$ liver, respectively, $P<0.5)$, and both were much lower than 30-day-old and adult dogs (46.3 \pm 33.7 and $30.8 \pm 17.6$, respectively, $P<0.5$ ). Comparison with the pattern of development of catalase and acid phosphatase demonstrated nonparallelism with uricase activity lagging behind both other enzymes. Plasma urate concentrations of $0.66 \pm 0.09$ (S.D.) $\mathrm{mg} / \mathrm{dl}$ in fetal animals were higher than the maternal plasma value $\mathbf{( 0 . 2 2}$ $\mathrm{mg} / \mathrm{dl})$, which appears to exclude the possibility that low fetal uricase activity was the result of decreased enzyme substrate.

The mongrel puppy has been used as an animal model for studying neonatal development of renal uric acid excretion and has been found to exhibit maturational patterns of urate excretion similar to human newborns (14). Despite diminishing fractional renal excretion of uric acid in the first 30 days of life, plasma uric acid concentration also decreases. Uricase, which metabolizes uric acid to allantoin, is present in hepatocytes from most mammals $(5,10)$ (anthropoid primates and man being major exceptions (10)) and serves to maintain plasma uric acid at concentrtations much lower than those observed in man. The Dalmatian coach hound has a plasmic uric acid concentration much higher than other dogs, a metabolic derangement thought to be due to inaccessibility of uric acid to the enzyme that is present in adequate quantities in liver $(6,17)$. The defect is corrected by hepatic transplant (8). Because of these observations, we proposed that the observed elevated plasma uric acid in the newborn mongrel puppy might be due to insufficient activity of hepatic uricase. The purpose of these experiments was to determine hepatic uricase activity in late fetal, neonatal, and adult dogs to demonstrate the proposed inverse relationship between uricase activity and plasma uric acid concentration.

\section{MATERIALS AND METHODS}

Mongrel dogs which had been housed in the University of Tennessee Animal Resources Division vivarium and maintained on standard Purina dog chow (mature canines) or on mothers' breast milk were sacrificed by excision of the liver during deep pentobarbital anesthesia followed by anesthetic overdose. Six near-term fetal animals (weighing $227 \pm 12 \mathrm{~g}$ ) were obtained by Caesarean section while the mother was maintained under deep pentobarbital anesthesia. After removal, the livers were blotted dry with laboratory towels and weighed immediately. The entire liver of smaller animals or $5 \mathrm{~g}$ from each lobe of larger animals was minced in three volumes of ice cold $0.25 \mathrm{M}$ sucrose containing $0,001 \mathrm{M}$ Na-EDTA (sucrose-EDTA) and transferred to a PotterElvehjem tube where it was homogenized by ten strokes with a loosely fitting pestle. Light mitochondrial fractions were prepared according to de Duve et al. (4), washed once with sucrose-EDTA, and resuspended to a concentration equivalent to the original $25 \%$ homogenate. Aliquots were stored at $-20^{\circ} \mathrm{C}$ for less than 30 days.

Uricase (urate:oxygen oxoreductase, EC 1.7.3.3) activity was determined at saturation kinetics by the method Schneider and Hogeboom (13) using as substrate $250 \mu \mathrm{M}$ uric acid in $30 \mathrm{mM}$ potassium phosphate buffer, $\mathrm{pH} 7.4$, containing $0.1 \%$ Triton X100. The reaction was initiated by the addition of enzyme to substrate in cuvettes maintained at $37^{\circ} \mathrm{C}$ by a circulating water bath. The decline in absorbance at $290 \mathrm{~nm}$ was monitored by a recording dual-beam Zeiss DM-4 spectrophotometer. Activity was calculated as $\mu$ mole urate oxidized $/ \mathrm{min} / g$ wet liver, assuming $E_{290}=$ $12.2 \times 10^{3} \mathrm{~mole}^{-1} \cdot \mathrm{cm}^{-1}$.

Catalase (hydrogen peroxide: hydrogen peroxide oxidoreductase, EC 1.11.1.6) was determined by the method of Beers and Sizer (1) using $0.1 \% \mathrm{H}_{2} \mathrm{O}_{2}$ in $50 \mathrm{mM}$ potassium phosphate buffer, $\mathrm{pH} 7.4$, as substrate. The reaction was carried out at $37^{\circ} \mathrm{C}$, and the decline in absorbance at $240 \mathrm{~nm}$ was recorded. Activity was calculated as $\mu$ mole $\mathrm{H}_{2} \mathrm{O}_{2}$ hydrolysed/min/g liver, assuming $\mathrm{E}_{240}$ $=27.4 \mathrm{~mole}^{-1} \cdot \mathrm{cm}^{-1}$.

Acid phosphatase (EC 3.1.3.2) activity was determined using as substrate $50 \mathrm{mM}$-nitrophenylphosphate in $1 \mathrm{M} \mathrm{Na}$-acetate buffer, pH 5.7, containing $100 \mathrm{mM} \mathrm{MgCl}_{2}$ (2). A 10-min incubation at $37^{\circ} \mathrm{C}$ in a shaking water bath was followed by alkalinization and measurement of the absorbance at $405 \mathrm{~nm}$ versus a reagent blank. Activity was calculated as $\mu$ mole $p$-nitrophenylphosphate hydrolysed $/ \mathrm{min} / \mathrm{g}$ liver assuming, $\mathrm{E}_{405}=18.8 \times 10^{6} \mathrm{~mole}^{-1}$. $\mathrm{cm}^{-1}$.

Enzyme assays were linear with respect to time and enzyme concentration, and activity was not reduced by storage at $-20^{\circ} \mathrm{C}$ for $\mathbf{3 0}$ days. All assays were performed within this time. Chemicals were all reagent grade from Sigma Chemical Co. Plasma uric acid concentrations were determined by a fluorometric method previously described (14).

All statistical analysis was by Student's $t$ test for unpaired data.

\section{RESULTS}

The specific activities of uricase, catalase, and acid phosphatase are given in Table 1 . The dogs numbered $2,3,4$, and 14 died during the course of experiments in which we were attempting to serially measure activities of enzymes in liver obtained by percutaneous biopsy: the data are excluded. Inspection of the data illustrates that uricase activity sharply increases from late fetal and early neonatal values to those at 30 days and in adult dogs $(P<0.05$ 
Table 1. Enzyme activity of canine hepatic enzymes

\begin{tabular}{|c|c|c|c|c|}
\hline $\begin{array}{l}\text { Dog } \\
\text { Number }\end{array}$ & Age & $\begin{array}{c}\text { Uricase } \\
\mu \mathrm{mole} / \mathrm{min} / \mathrm{g} \\
\times 10^{5}\end{array}$ & $\begin{array}{c}\text { Catalase } \\
\mu \mathrm{mole} / \mathrm{min} / \mathrm{g}\end{array}$ & $\begin{array}{c}\text { Acid } \\
\text { phosphatase } \\
\mu \mathrm{mole} / \mathrm{min} / \mathrm{g} \\
\times 10^{7}\end{array}$ \\
\hline 1 & Adult & 60.1 & 57.2 & 28.6 \\
\hline 5 & Adult & 28.6 & 17.5 & 10.7 \\
\hline 6 & Adult & 12.4 & 7.6 & 6.9 \\
\hline 7 & Adult & 25.4 & 21.6 & 15.1 \\
\hline 8 & Adult & 27.6 & 14.0 & 21.2 \\
\hline 12 & $30 \mathrm{~d}$ & 101.8 & 67.1 & 44.4 \\
\hline 13 & $30 \mathrm{~d}$ & 31.8 & 35.0 & 12.7 \\
\hline 15 & $30 \mathrm{~d}$ & 18.6 & 52.5 & 25.7 \\
\hline 16 & $30 \mathrm{~d}$ & 25.4 & 46.7 & 18.6 \\
\hline 17 & $30 \mathrm{~d}$ & 53.9 & 109.8 & 26.5 \\
\hline 26 & $16 \mathrm{~d}$ & 9.5 & 64.2 & 22.2 \\
\hline 27 & $16 \mathrm{~d}$ & 8.0 & 89.9 & 30.9 \\
\hline 9 & $1 \mathrm{~d}$ & 3.2 & 14.0 & 12.7 \\
\hline 10 & $1 \mathrm{~d}$ & 4.2 & 18.1 & 10.7 \\
\hline 11 & $1 \mathrm{~d}$ & 4.8 & 29.2 & 26.0 \\
\hline 18 & $1 \mathrm{~d}$ & 4.2 & 12.8 & 7.6 \\
\hline 19 & $1 d$ & 3.2 & 25.6 & 12.1 \\
\hline 20 & Fetal & 0.5 & 4.7 & 9.1 \\
\hline 21 & Fetal & 1.0 & 9.9 & 9.8 \\
\hline 22 & Fetal & 1.0 & 29.2 & 12.7 \\
\hline 23 & Fetal & 0.7 & 7.0 & 11.2 \\
\hline 24 & Fetal & 1.7 & 23.3 & 10.5 \\
\hline 25 & Fetal & 3.3 & 37.4 & 12.3 \\
\hline
\end{tabular}

for differences between mean activities of adult or $\mathbf{3 0}$ day dogs versus fetal or one day pups). Catalase and acid phosphatase activities are not significantly increased during this same time period. The values of all three enzyme activites tended to be higher in $\mathbf{3 0}$ day pups than in adult animals although the differences were not significant $(P>0.05)$.

Figure 1 illustrates the pattern of development of uricase activity. For comparison, the activities of the three hepatic enzymes have been normalized: individual values are divided by the mean adult value of the respective enzyme activity and the results are given as a fraction of the mean adult value. This plot exemplifies further that hepatic uricase activity increases sharply during the first month of life. The ratios of uricase/catalase and uricase/acid phosphatase, similarly standardized, demonstrate the lack of parallelism of hepatic enzyme development. The specific activity of uricase is diminished when compared to either catalase or acid phosphatase during early development.

To determine if the delayed activity of hepatic uricase was due to absence of substrate during the fetal period, we examined fetal plasma uric acid concentration within one minute of Caesarian section. The uric acid concentration of plasma from six fetal dogs was $0.66 \pm 0.09 \mathrm{mg} / \mathrm{dl}( \pm$ S.E.M.), a value 3 -fold higher than the maternal plasma urate of $0.22 \mathrm{mg} / \mathrm{dl}$.

\section{DISCUSSION}

Our data suggest that the observed fall in plasma uric acid concentration from a mean value of $0.90 \mathrm{mg} / \mathrm{dl}$ in the 1-day-old puppy to 0.21 in the adult (14) is due principally to the increasing activity of hepatic uricase during the first month of life. These observations explain our previous observations of falling plasma uric acid concentration despite diminished fractional renal excretion.

Peroxisomes are recognizable subcellular organelles containing the enzymatic activities of uricase and catalase. In mammals they

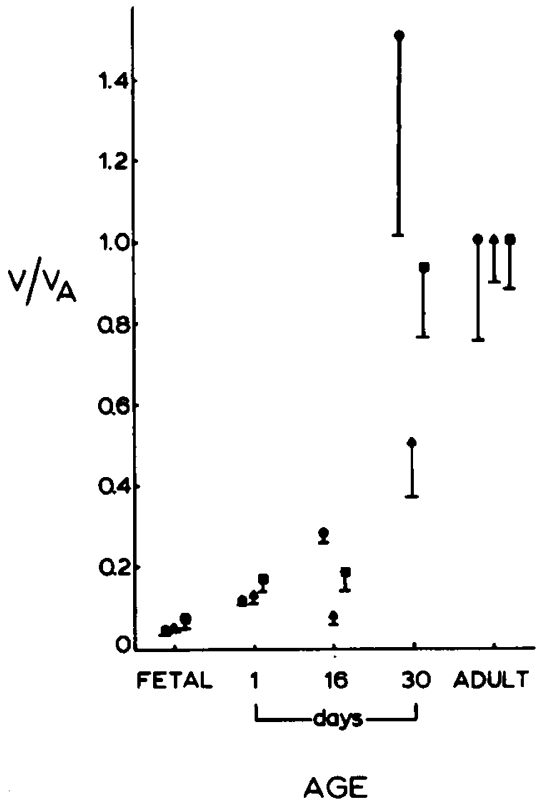

Fig. 1. The pattern of development of hepatic peroxisomal uricase. Uricase activity $(O)$ and the ratio of uricase/catalase $(\Delta)$ and uricase/acid phosphatase (D) are normalized by dividing by the mean adult value. Mean values are plotted versus the age. The crossed bar indicates one S.E.M.

are concentrated in hepatic and renal tissues. Canine kidney tissue has been shown to lack uricase activity (12); the liver appears to be the primary determinant of plasma uric acid in dogs. Kuster $e t$ al. (8) provided evidence for this association by transplanting livers from mongrel dogs into Dalmatians, which normally maintain high plasma urate concentrations, and demonstrating normalization of plasma concentration. Transplanting liver from Dalmatian into mongrel dogs produced Dalmatian-like elevation in plasma concentration. This defect is evidently due to a defect in transport of urate into cells (17) and not due to an absence of enzymatic activity in liver (6). Based on our data, we conclude that the elevated plasma urate concentrations in fetal and 1-dayold puppies is due to an immaturity of hepatic uricase activity.

Fetal and neonatal liver (not canine) have been investigated with regard to peroxisomal enzyme development. In the mouse, uricase activity is very low at birth and increases more than 15fold during the suckling period (9). Rat liver exhibits a very sharp increase in catalase activity at birth and a more gradual increase in uricase activity spanning the first 2 or 3 wk of life $(7,15)$. The pig likewise has a neonatal defect in uricolytic activity (11). Our studies add to these observations by demonstrating a developmental pattern of uricase activity in the puppy that is similar to the mouse, rat and pig; moreover, we have shown a physiologic response in urate metabolism related to enzyme development while other investigators have not reported such observations.

We compared the pattern of development of uricase with another peroxisomal enzyme, catalase, and a lysosomal enzyme isolated in the same tissue fraction, acid phosphatase. Our data demonstrate delayed development of uricase relative to both these enzymes. Uricase is located in the core of the peroxisome whereas catalase is associated with the membrane (10). Previous data indicate that the development of uricase activity in rat liver proceeds by four mechanisms: formation of peroxisomes, formation of nucleoids within peroxisomes, maturation of nucleoids (increasing specific activity of enzyme within nucleoids), and growth of nucleoids (16). Our data suggest a delay in formation, maturation, or growth of nucleoids because enzyme development is nonparallel within peroxisomes, uricase activity being delayed compared to catalase. Peroxisomes appear to form at a rate equivalent to lysosomes as demonstrated by similar patterns of catalase and acid phosphatase development. 
The cause of the delay in uricase development is unknown. We hypothesized that it could have resulted from placental transport maintaining a low plasma concentration in the fetus. Birth would remove this mechanism and result in substrate excess and enzyme induction; however, we showed that fetal plasma urate concentrations are similar to those seen in the newborn (14) and higher than maternal values, essentially disproving our hypothesis. Possibly birth itself initiates development as it does microsomal development (3).

\section{REFERENCES AND NOTES}

1. Beers, R. F. and Sizer, I. W.: A spectrophotometric method for measuring the breakdown of hydrogen peroxide by catalase. J. Biol. Chem., 195: 133 (1952).

2. Cooper, T. G.: The Tools of Biochemistry. p. 398. (John Wiley and Sons, New York, 1977)

3. Cukier, J. O., Whitington, P. F., and Odell, G. B.: The bilirubin, UDP-glucuronyl transferase of liver in post-mature rats: a functional and morphologic comparison. Lab. Invest., 44: 368 (1981).

4. de Duve, C., Pressman, B. C., Gianetto, R., Wattiaux, R., and Appelmans, F.: Tissue fractionation studies: 6 . Intracellular distribution patterns of enzymes in rat liver tissue. Biochem. J., 60: 604 (1955).

5. de Duve, C. and Baudhuin, P.: Peroxisomes (microbodies and related particles). Physiol. Rev., 46: 323 (1966)

6. Klemperer, F. W., Trimble, H. C., and Hastings, A. B.: The uricase of dogs, including the Dalmation. J. Biol. Chem., 125: 445 (1938)

7. Krahling, J. B., Gee, R., Gauger, J. A., and Tolbert, N. E.: Postnatal development of peroxisomal and mitochondrial enzymes in rat liver. J. Cell. Physiol., 101: 375 (1975).

8. Kuster, G. Shorter, R. G., Dawson, B., and Hallenbeck, G. A.: Uric acid metabolism in Dalmations and other dogs. Arch. Intern Med., 129: 492 (1972).

9. Lee, P. C.: Developmental changes of adenosine deaminase, xanthine oxidase, and uricase in mouse tissues. Develop. Bio., 31: 227 (1973)

10. Masters, C. and Holmes, R.: Peroxisomes: New aspects of cell physiology and biochemistry. Physiol. Rev., 57: 816 (1977).

11. Mendel, L. B. and Mitchell, P. H.: Chemical studies on growth II. The enzymes involved in purine metabolism in the embryo. Am. J. Physiol., 20: 97 (1907).

12. Quebbeman, A. J., Cumming, J. D., Shideman, J. R., and Toledo-Pereyra, L.: Synthesis of uric acid in isolated normothermic perfused mongrel and Dalmation dog kidneys. Am. J. Physiol., 228: 959 (1975).

13. Schneider, W. C. and Hogeboom, G. H.: Intracellular distribution of enzymes. IX. Certain purine-metabolizing enzymes. J. Biol. Chem., 195: 161 (1952).

14. Stapleton, F. B. and Arant, B. S., Jr.: Ontogeny of renal uric acid excretion in the mongrel puppy. Pediatr. Res., 15: 1513 (1981).

15. Stevens, L.: A comparative study of enzymes in foetal, young, and adult rat. Comp. Biochem. Physiol., 6: 129 (1962).

16. Tsukada, H., Mochizuki, Y., and Konishi, T.: Morphogenesis and development of microbodies of hepatocytes of rats during pre- and postnatal growth. J. Cell. Biol., 37: 231 (1968).

17. Yu, T., Gutman, A. B., Berger, L., and Kaung, C.: Low uricase activity in the Dalmation dog simulated in mongrels given oxonic acid. Am. J. Physiol., 220: 973 (1971).

18. Requests for reprints should be addressed to: Dr. Peter F. Whitington, LeBonheur Children's Medical Center, 848 Adams Avenue Memphis, Tennessee 38103.

19. This work was supported by New Faculty Grant \#H-00047 (FBS)

20. Received for publication July $1,1982$.

21. Accepted for publication December $9,1982$.

\title{
Studies on Bile-Salt-Stimulated Lipolytic Activity in Human Milk. II Demonstration of Two Groups of Milk with Different Activities
}

\author{
BARBARA HALL AND D. P. R. MULLER ${ }^{(17)}$ \\ Department of Child Health, Institute of Child Health, 30 Guilford Street, London, WCIN IEN, England
}

Summary

Human milk samples were assayed for bile-salt-stimulated ifpolytic activity in the presence of an unpurified and purified preparation of glycoconjugated bile salts and two patterns of activity were obtained. One group of milks (high activity) had similar activities (mean \pm 1 S.D.) of $16.9 \pm 3.5$ (purified bile salts) and $17.2 \pm 3.5 \mu \mathrm{mole} \cdot \mathrm{ml}^{-1} \cdot \mathrm{h}^{-1}$ (unpurified bile salts) whereas another group (low activity) had a lower activity with the purified (4.2 $\pm 2.3 \mu \mathrm{mole} \cdot \mathrm{ml}^{-1} \cdot \mathrm{h}^{-1}$ ) than with the unpurified bile salt preparation $\left(19.9 \pm 4.0 \mu \mathrm{mole} \cdot \mathrm{ml}^{-1} \cdot \mathrm{h}^{-1}\right)$.

Activities of the low activity milks (assayed with the purified bile salts) could be increased following storage at $-20^{\circ} \mathrm{C}$, sonication, or the preparation of an acetone ether powder and, in some cases, reached the maximal activity obtained with the unpurified bile salt preparation. These procedures had no effect on the activity of the high activity milks.

Recombination experiments, whereby the milk serum from a low activity milk was added to the milk fat of a high activity milk and vice versa, and also kinetic studies suggest that the differences in activities between the two groups result from differences in availability of the enzyme and are independent of the source of milk fat.
Human milk contains at least two different lipases. First, a lipase that requires added serum for activity and has properties similar to lipoprotein lipase (12) and second, a lipase that is stimulated by bile salts (11). The latter activity appears to be ideally suited for a physiologic role in the small intestine of the newborn. It remains active during passage through the stomach as it is stable above pH 3.5 and only slowly inactivated by pepsin (10). The optimal bile salt concentration for activity is around 2 mmole $\cdot \operatorname{liter}^{-1}(9,10)$, which is within the physiologic range found in the newborn $(2,5)$ and bile salts also protect the enzyme from tryptic inactivation (10).

In a previous paper (9) we described a procedure for the assay of the bile-salt-stimulated lipase activity using human milk as both the source of enzyme and substrate, and reported some properties of this enzyme and its nutritional implications. We now report some additional studies which suggest that in human milk, the bile-salt-stimulated lipase forms a close relationship not only with its substrate but also with other components of milk that may regulate its activity.

\section{SUBJECTS AND METHODS}

Subjects. In total, 59 samples of human milk were collected from 24 women from the 2 nd day to the 72 nd wk postpartum. 